LEHOTAY Veronika

egyetemi adjunktus

ME ÁJK
DOI: 10.15170/DIKE.2018.02.01.02

\title{
A Miskolci Királyi Ügyészség tevékenysége 1938 és 1944 között
}

\section{The Activity of the Crown Prosecution Service of Miskolc between 1938 and 1944}

In the second part of the Horthy era (1938 - 1945), the prosecution sercive of Miskolc had a total of 3.279 ongoing cases of which 23 were procedures related to anti-Jewish laws. A significant part of the 23 procedures terminated already in the investigation phase and only 2 of them reached the court. The study of these 23 cases reflects that the prosecution service conducted a comprehensive investigation and it rather dropped the charges if the proof resulted to be insufficient. We can state that the prosecution service of Miskolc handled the few cases related to anti-Jewish laws very "carefully", and its practice was not as discriminating as the legal frame would have allowed.

Keywords: Crown Prosecutor of Miskolc, anti-Jewish laws, discrimination, Horthy era

\section{Bevezető gondolatok}

„A napilapokban minden nap lehet olvasni, hogy itt és ott is fajgyaláaásért zsidót itélt el a biróság, itt Miskolcon ilyen fajgyalázási eset nyomozásáról, illetve kideritéséröl olvasni még nem lehetett. Pedig itt is van. Kérem a rendör nyomozó urakat Vörösmarty út 65 sqám alatti lakás (szuterin) pincébe egy zisidó ember él ott egy keresztén lánnyal már figyelmertetve volt, hogy hagyjon fel a dolgaival, mert az ö eljárása helytelen és az. büntetést von maga után" írja egy olvashatatlan aláírású feljelentő 1942-ben a Magyar Királyi Államrendőrség miskolci búnügyi osztályának címzett feljelentésében. ${ }^{1}$ Milyen szerepe volt a Miskolci (Királyi) Államügyészségnek az 1938 és 1944 között született zsidótörvények alapján indított eljárások megindításában, foganatosításában, a diszkriminatív joggyakorlat megvalósításában? A tanulmányban erre a kérdésre keresem a választ, amely kiegészítésül szolgálhat a Schweitzer Gábor által feltett kérdésre, hogy a jogszolgáltató szervek mennyiben lassították vagy gyorsították a zsidóság jogi, politikai, gazdasági és társadalmi diszkriminációját, milyen mértékben segítették elő azt, hogyan járultak hozzá a megalkotott és többé-kevésbé végrehajtott rendelkezések értelmezéséhez. ${ }^{2}$ Korábban a három hatalmi ág múködését kutattam a diszkriminatív intézkedések tükrében az 1938 és 1944 közötti időszakban, a harmadik hatalmi ágon belül pedig a zsidótörvények Curiai joggyakorlatát vizsgáltam. ${ }^{3}$ Ennek a kutatásnak a során jöttem rá arra, hogy a zsidótörvényeket alkalmazó felsőbb bíróságok gyakorlata, az ehhez kapcsolódó helyi bírósági gyakorlat, valamint az ügyészség múködése is jelentôs mértékben feltáratlan területe a

\footnotetext{
${ }^{1}$ MNL BAZML VII. 51/b. 427. IV. 6893/1943.

2 SCHWEITZER, A zsidótörvények a Közigazgatási Bíróság ítélkezési gyakorlatában 164-175.

${ }^{3}$ LEHOTAY, Szabadságjog-megvonó intézkedések 4-326.
} 
jogtörténetnek. Így míg a korábbi kutatásomban csak a Curiai joggyakorlatra helyeztem a hangsúlyt a szakirodalomban és az Országos Levéltárban fellelhető források alapján, addig a jelenlegi kutatást a helyi szintű jogszolgáltató szervek dokumentumainak feltárásával kezdtem el. Ezek még a kutatás kezdő lépései. A tanulmány három részre oszlik. Az első részben a kutatás forrásaival, az eddig rendelkezésre álló adatokkal foglalkozom, majd általában a (miskolci) ügyészség előtti jogesetek statisztikáját, jellemzőit mutatom be a vizsgált korszakban, végül pedig a rendelkezésre álló zsidótörvényekkel kapcsolatos Borsod megyei ügyészségi eljárások jellegzetességeit vázolom fel.

\section{A kutatás forrásairól}

A kutatás első lépése annak tisztázása, hogy milyen adatok állnak eddig rendelkezésünkre a zsidótörvényekkel összefüggő ügyészségi eljárásokról országos és helyi szinten. Léteznek a bírói gyakorlatra vonatkozó kutatások és statisztikai adatok, ezek azonban nem teljes körúek, hanem a zsidótörvényekkel összefüggő eljárások egy-egy területére terjednek ki (elsősorban a fajgyalázási perekre valamint a zsidótörvény kijátszásával összefüggő esetekre.) Történeti, társadalomtörténeti, jogtörténeti megközelítéseket is találunk a szakirodalomban. Ezek tanulmányozása során kiderült, hogy a zsidótörvényekkel kapcsolatos eljárásokra, különösen az ezzel összefüggő bírói gyakorlatra

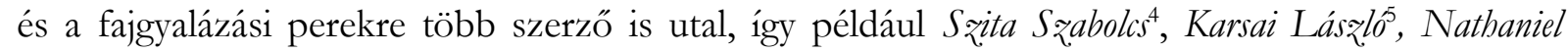
Katz̧burg és Nagy Sándor. S Sqita a Haláleród című könyvében utalt arra, hogy a fajgyalázás mellett jelentős számban megnövekedett a zsidók ellen többféle ürüggyel indított, zömében „koholt perek” száma, részletesen azonban nem foglalkozott ezeknek az ügyeknek a bemutatásával. ${ }^{8}$ Karsai a fajgyalázási perekkel kapcsolatban azt emelte ki, hogy az eddigi kutatások alapján rendkívül ritkák az ilyen esetek. ${ }^{9}$

A fajgyalázási perek társadalomtörténeti megközelítésével - ahogy arra Nagy Sándor is utalt tanulmányában - foglalkozott Lugosi András ${ }^{10}$ és Szegedi Gábor. ${ }^{11}$ Nagy - aki ugyancsak nem kifejezetten az ügyészséggel foglalkozott - A fajvédelem útvesztójében címú tanulmányában a fajgyalázási pereket vizsgálta. Ő egyrészt azt rögzítette, hogy a történészek döntő többsége egyetért azzal, hogy a harmadik zsidótörvény házasságon kívüli zsidó-keresztény nemi viszonyra, „fajgyalázásra” vonatkozó 15. \-t a gyakorlatban nem vagy csak elvétve alkalmazták, másrészt viszont rámutatott arra is, hogy „a kép ettöl összetettebb és mindenképpen árnyaltabb”. ${ }^{12}$ Különbség van szerinte a büntető igazságszolgáltatás különböző szintjeinek működését, ügyforgalmát jelző adatok között városi és vidéki szinten. Míg vidéken viszonylag ritkán került sor fajgyalázás miatt indított büntetőeljárásra, addig Budapesten (ahol a zsidóság 2/3-a élt) jelentős számú ilyen eset volt. Nagy statisztikai adatokat is közölt: országos statisztika csak az 1942-ben jogerősen befejezett fajgyalázási

\footnotetext{
${ }^{4}$ SZITA, Halálerőd 15.

${ }^{5}$ KARSAI, A magyarországi zsidótörvények és rendeletek 140-163.

${ }^{6}$ KATZBURG, Zsidópolitika Magyarországon 153-162.

${ }^{7}$ NAGY, A fajvédelem útvesztőjében 487-588.

${ }^{8}$ SZITA, Halálerőd 15.

${ }^{9}$ KARSAI, A magyarországi zsidótörvények és rendeletek 132.

${ }^{10}$ LuGOSI, „Sztalin főhercege”527-576.

11 SZEGEDI, Good Health is the Best Dowry 307-317.

${ }^{12}$ NAGY, A fajvédelem útvesztőjében 488.
} 
ügyekről készült, eszerint viszont ebben az évben nem kevesebb mint 707 alkalommal tettek feljelentést ,fajvédelmi törvénybe ütkö̃ő" büntett’ miatt. ${ }^{13}$ Ezek közül 605 esetben az eljárás nem jutott bírói szakaszba; a törvényszékek 102 ilyen pert tárgyaltak; 61 esetben hoztak marasztaló, 41 alkalommal pedig felmentô ítéletet. ${ }^{14}$ Ezekből az adatokból nem derül ki, hogy mely törvényhatóságokban indultak az eljárások. Budapesten az 1941-ben és 1942-ben lezárt rendőrségi nyomozásokról áll rendelkezésre publikált statisztika: eszerint a fővárosban a törvény életbe lépése (1941. október 10.) utáni két és fél hónapban 104 megindult nyomozást sikerült lezárni; a következő teljes évben ez a szám 1.459-re ugrott. ${ }^{15}$ Arról azonban nem rendelkezünk statisztikai adatokkal sem országos, sem pedig helyi szinten, hogy az ügyészségek előtt összesen hány zsidótörvénnyel kapcsolatos eljárás indult, mert ebbe a számba azok az esetek is beletartoznak, amelyek már ügyészi szakban lezárultak, tehát nem is kerültek a bíróságok elé.

A magyarországi ügyészség történetével a legrészletesebben Nánási László a 2011-ben megjelent „A magyar királyi ügyészség története 1871 - 1945 között” címú monográfiájában foglalkozott. ${ }^{16}$ Ó mutatott rá arra, hogy a jogtörténet kutatói az igazságszolgáltatáson belül alapvetően a bíróságok történetére koncentráltak, azonban az ügyészségről átfogó munka nem született. Ugyancsak Nánási utalt az ügyészségre vonatkozó levéltári források hiányosságaira is, ami mind központi, mind pedig területi szinten jellemző. ${ }^{17}$ A Magyar Országos Levéltárban az Igazságügyi Minisztérium anyagának jelentős része az 1956-os tűzvész során megsemmisült. Az egyes megyékben is eltérően alakult az iratanyag sorsa. Így egyes megyékben jelentős az iratanyagveszteség (Békés, Fejér, Tolna, Veszprém), míg más megyékben viszonylag sok irat maradt meg (Budapest, Csongrád). ${ }^{18}$ Bár Nánási külön nem említette, de Borsod megye is ebbe az utóbbi kategóriába sorolható. Monográfiájában külön fejezetben tárgyalta az 1938 és 1944 közötti időszakot „A területi visszacsatolások és a II. világháború korszaka” címen. ${ }^{19}$ Mindössze néhány sorban utalt a zsidótörvényekre, amelyek „(...) a korszak politikai igényeinek megfelelö tényállásokat jelentettek”” ${ }^{20}$ Ebben a részben ismertette az 1938-ban megalkotott államvédelmi törtvényjavaslat indokolását, amelyben a kormány szerint az ügyészség „,...) a büntetô igazságszolgáltatásnak elsô, legfontosabb és mindenek fölött álló hivatása, hogy az, anyagi igasság kideritése mellett megvédje a törvényes jogrendet. El kell távolitani mindazokat az akadályokat, amelyek az eljárás gyors lefolytatását, a hatályos és gyors felelósségre vonás és megtorlás lehetôségét feleslegesen hátráltatják". ${ }^{21}$

Ezeknek a céloknak a megvalósítására és az ügyészség hatáskörének növelésére született meg két törvény 1938-ban. ${ }^{22}$ Az 1930-as évek végétől megalkotott jogszabályok tehát az igazságszolgáltatás múködését is lényegesen befolyásolták. Egyrészt az 1939. évi IV. tc. alapján

\footnotetext{
13 NAGY, A fajvédelem útvesztőjében 488.

${ }^{14}$ NAGY, A fajvédelem útvesztőjében 488.

15 NAGY, A fajvédelem útvesztőjében 488.

${ }^{16}$ NÁNÁSI, A magyar királyi ügyészség története 365.

${ }^{17}$ NÁNÁsI, A magyar királyi ügyészség története 8.

${ }^{18}$ NÁNÁsI, A magyar királyi ügyészség története 8.

19 NÁNÁsI, A magyar királyi ügyészség története 290-338.

${ }^{20}$ NÁNÁsI, A magyar királyi ügyészség története 380.

21 A képviselőházi naplóból idézi: NÁNÁsI, A magyar királyi ügyészség története 376.

${ }^{22} \mathrm{Az}$ állami rend megóvása végett szükséges büntetőjogi rendelkezésekről szóló 1938. évi XVI. tc. valamint az állami rend megóvása végett szükséges sajtórendészeti rendelkezésekről szóló 1938. évi XVIII. tc. Lásd hozzá NÁNÁSI, A magyar királyi ügyészség története 376.
} 
megtörtént a bíróságok, ügyészségek faji alapú „megtisztitása”. Másrészt az ügyészség feladatai bővültek (sajtócenzúra, katonai bűncselekmények, statárium, zsidótörvények), ezért az ügyészségi szervezet létszáma is növekedett. Ezekben az években egy külön ügyészi szerv is múködött a közélet tisztasága elleni bűncselekmények ellen és a velük szembeni fellépés érdekében. Nánási röviden utalt a második zsidótörvény és végrehajtási rendelete alapján bekövetkezett személyzeti változásokra is, amelyekre hivatkozással két ügyész mint „tisz̨ta zsidó fajú egyén” nyugdijazásra került, másik két ügyészt pedig mentesítettek. ${ }^{23}$ Ezt követően - személyi kérdésében - nyilatkoznia kellett arról az előterjesztőnek, hogy „olyan származási körülmények, amelyek a kineveztetésnek akadályai lehetnének, nem forognak fenn." 24

Az ügyészség elé kerülő, növekvő számú bűnügyekről közölt Nánási statisztikai adatokat, amelyekbe 1938-tól a zsidótörvények alapján indított eljárások is beletartoztak. Így 1940-ben 143.851, 1941-ben 222.101, 1942-ben 223.161, 1943-ban pedig összesen 284.558 eljárás indult az ügyészségek előtt. ${ }^{25}$ Nánási azonban általában foglalkozott az ügyészség történetének a bemutatásával, így tehát a zsidótörvényekkel kapcsolatos eljárásokra részletesen nem tért ki, a fajgyalázásra utalt a háborús büntetőjogi tényállások (mint például a tiltott gyülekezés, kivándorlásra csábítás, árdrágítás, áruelrejtés, rémhírterjesztés, tiltott határátlépés) körében. ${ }^{26}$ Továbbá bemutatta a fajvédelmi törvény végrehajtásával kapcsolatos 70651/1941. IM. IV. számú leiratot, amely az ügyészségeket az eljárások ,erélyes vitelére utasitotta”. ${ }^{27}$ Ugyanakkor arról is írt a szerző, hogy ezeknél a tényállásoknál a legszemélyesebb viszonyokról kellett a nyomozó hatóságnak információkat gyújteni, ezért ezek a nyomozások általában eredmény nélkül értek véget. ${ }^{28}$ Ez utóbbi állítást, ahogy az a jelen tanulmány későbbi részében látható lesz, a jelenlegi kutatás eredményei is alátámasztják. Kifejezetten a miskolci ügyészségre vonatkozóan szakirodalmat a vizsgált korszakra vonatkozóan nem találtam. Így az ügyészség munkáját a levéltári források segítségével lehet feltárni, amelyek a Borsod-Abaúj-Zemplén Megyei Levéltár alsózsolcai fióklevéltárában találhatók.

\section{Eljárások a Miskolci Királyi Ügyészség előtt 1938 és 1944 között}

A szakirodalom csak érintőlegesen utal a miskolci ügyészségre. Így például a zsidók internálásával összefüggésben került említésre. Az 1941-ben hatályba lépett harmadik zsidótörvény egyik következménye a zsidó szervezetek feloszlatása, vagyonuk elkobzása volt. 1942. április 15-én így kapta az utasítást Fekete Bertalan polgármester (1938 - 1943), hogy a belügyminiszter a Miskolci Kereskedők és Gazdák Körét feloszlatta, ezért a polgármester az ezzel kapcsolatos eljárásokat azonnal tegye meg. 1942. április 30-án már Borbély-Mačkyy Emil főispán, a VII. Honvéd Hadtest Országmozgósítási Kormánybiztosa utasította a rendőrhatóságokat, hogy „a zsidókkal és megbiø̧̧atatlan egyénekekel követendô" eljárásnak maradéktalanul tegyenek eleget. Az utasítás a zsidók és az agitátorok internálásáról, vagy az ügyészségnek történő azonnali átadásukról szólt. A magyarázat

\footnotetext{
${ }^{23}$ NÁNÁSI, A magyar királyi ügyészség története 393.

${ }^{24}$ NÁNÁsI, A magyar királyi ügyészség története 393.

${ }^{25}$ NÁNÁsI, A magyar királyi ügyészség a II. világháború idején 270-271.

${ }^{26}$ NÁNÁSI, A magyar királyi ügyészség története 409.

${ }^{27}$ NÁNÁSI, A magyar királyi ügyészség története 410.

${ }^{28}$ NÁNÁSI, A magyar királyi ügyészség története 410.
} 
csupán ennyi: „Rendelkezésem nem sqorul indoklásra. Annak végrehajtására érvényben lévô jogszabályok módot nyújtanak. Komoly idôket élünk. Itt az. ideje a legerélyesebb intézkedéseknek. “29

A jogkorlátozó szabályok betartása a büntetőjog feladata lett. Hogyan alakult az ügyészség tevékenysége Miskolcon? Milyen eljárásokra került sor a Miskolci Királyi Ügyészség előtt 1938 és 1944 között? Milyen adatok derülnek ki a miskolci királyi ügyészség dokumentumaiból? Mennyiben cáfolják vagy erôsítik meg a korábbi (főleg a bírósági gyakorlattal foglalkozó) kutatások eredményeit a rendelkezésre álló levéltári iratok? A borsodi levéltárban az ügyészségre vonatkozó iratok jelentős része megmaradt és kutatható. Az iratok között találunk a megszokott eljárások mellett (mint pl. lopás, gyújtogatás, okirathamisítás, izgatás) rémhírterjesztés, nemzetgyalázás, kormányzósértés, honvédelem elleni izgatás, fegyveres erő elleni izgatás, izgató nyomtatványok terjesztése, állam és társadalom elleni vétség, valótlanhír-terjesztés, tiltott sajtótermék terjesztése, nemzet megbecsülése elleni vétség miatt indított eljárásokat is. Milyen arányban került sor zsidótörvényekkel összefüggő eljárásokra? Az 1938 és 1944 közötti időszakban a Miskolci Királyi Ügyészség iratai szerint a rendelkezésre álló levéltári lista alapján összesen 3279 ügyből mindössze 23 zsidótörvénnyel kapcsolatos eljárás indult. Ebből 2 a zsidótörvény kijátszása, 11 a zsidótörvénybe ütköző vétség, 1 a zsidótörvénybe ütköző kihágás, 5 fajgyalázás, 3 zsidó bújtatás vétsége és 2 eljárás zsidó vagyon rejtegetése miatt indult. ${ }^{30}$ A 23 eljárásból 10-re 1940-ben, 2-re 1941-ben, 9-re 1943-ban és 2-re 1944-ben került sor. A kutatás még megválaszolatlan kérdése: mi lehet az oka annak, hogy ilyen kevés eljárás zajlott? Ez az évenkénti 3 eljárás a gyakorlatban azt jelenti, hogy voltak olyan évek (1938, 1939 és 1942), amelyekben egyáltalán nem volt zsidótörvény miatt indított eljárás a miskolci ügyészség előtt.

\section{Diszkriminatív(?) joggyakorlat a Miskolci Királyi Ügyészségen 1938 és 1944 között}

A zsidótörvénybe ütköző vétség miatti eljárások a második zsidótörvény, az 1939. évi IV. törvénycikk alapján zajlottak, de ezek nem azonosak a strómansággal. Ezeknek az eljárásoknak a lényege az volt, hogy az érintett személyt az országgyűlési képviselőválasztók névjegyzékébe felvették, de a második zsidótörvény szerint zsidónak minősült (vagy felmerült ennek a lehetősége), és így bejelentési kötelezettség terhelte, amelynek polgármesteri felhívás ellenére nem tett eleget. A levéltárban rendelkezésre álló esetek a törvényszéki hatáskörébe tartozó vétségnek minősültek az 1897. XXXIV. tc. 17. szakasza alapján. ${ }^{31}$

\footnotetext{
${ }^{29}$ BERÁNNÉ NEMES - ROMÁN, Miskolci története 290-291.

${ }^{30}$ MNL BAZML VII. 51/b.

31 1897. évi tc. XXXIV 17. \ A kir. törvényszékek hatásköréhez tartoznak: 1. azok a bűntettek, melyek a 15. 』 szerint az esküdtbiróságok hatásköréhez utasitva nincsenek; 2. az esküdtbiróságnak bűnösséget megállapitó itéletével már sujtott elmeműnek (1848. évi XVIII. tc. 27. \) ujra közlése vagy árulása által elkövetett bűntettek, vétségek és kihágások; 3. az 1878. évi V. tc. 258., 260., 261, és 262. \-aiban meghatározott vétségeknek azok az esetei, melyekben az eljárás a büntetőtörvénykönyv 269-272. \-ai értelmében hivatalból inditandó meg; 4. azok a vétségek, melyek a 18. \szerint a kir. járásbiróságok hatásköréhez utasitva nincsenek. Az 1878. évi V. tc. második részének I., II., III., IV. és XI. fejezetében körülirt bűntettek és vétségek, a mennyiben ezen \értelmében a kir. törvényszékek elé vannak utasitva, a kir. itélőtáblák székhelyén levő kir. törvényszékeknek, Budapesten a budapesti kir. büntető törvényszéknek kivételes hatáskörébe tartoznak. A budapesti kir. büntető törvényszéknek az 1887. évi XXVI. tc. 4. \-ában, illetőleg az 1895. évi XLIV. tc. 1. \-ában megállapitott kizárólagos hatásköre érintetlen marad.
} 
A nyomozás elrendelésekor az ügyész meghatározta a nyomozás konkrét irányát is: „Kihallgatandó gyanúsitott arra vonatkozólag, hogy a fenti törvény értelmében zsidónak kell-e öt tekinteni, amennyiben nem, igy ezt a lehetöséghez. képest okmányokkal kell igazolni. Kiballgatandó a tényállásra vonatkozólag is a védekerésig kiterjedô részletességgel. Kihallgatandók még mindazok, akiknek a vallomása bironyitékul szolgálhat. Beszerzendô" a gyanúsitott erkölcsi bizonyitványa." ${ }^{32}$ Két borsodi esetben a törvényszéki főtárgyalásra 1940. május 10-én került sor.

Az egyik vádlott a vádirat szerint E. Lajos 29 éves, római katolikus vallású, szabósegéd foglalkozású, miskolci születésű vádlott volt, akit az ügyészség az 1939. évi IV. tc. 26. szakaszának 1. pontjában meghatározott vétséggel azért vádolta, „mert Miskolcon 1939 év folyamán ma már közelebbröl meg nem állapitható idöben, mint a lajstromos országgyülési képviselöválas żók névjegyzékébe felvett, de az. 1939. évi IV. tc. 1. bek. szerint zsidónak tekintendö személy a második zsidótörvény és annak végrehajtási rendeleteiben elöirt bejelentési kötelezettségét annak ellenére elmulasztotta, hogy ezen kötelezettségére öt Miskolc polgármestere irásban figyelmę̧tette." 33 A vádirat indokolása szerint a terhelt kihallgatása során beismerte, hogy zsidó szülőktől származik, ezzel beismerte azt is, hogy az ún. zsidótörvény hatálya alá tartozik és bejelentési kötelezettségének a felhívás ellenére nem tett eleget. Védelmére azt hozta fel, hogy mint római katolikus vallású egyénnek nem kellett a bejelentési kötelezettséget teljesítenie. Az ügyészség azonban ennek ellenére megállapította a vádemeléshez szükséges törvényes feltételek meglétét.

Az E. József 32 éves, római katolikus vallású, miskolci születésű órássegéd elleni vádirat szinte szóról szóra megegyezik az előzô eljárásban elmondottakkal. A tényállás szerint a terhelt kihallgatása során beismerte, hogy bár ő már kereszténynek született, de a zsidótörvény hatálya alá esik. Beismerte azt is, hogy ezen kötelezettségének teljesítésére Miskolc város polgármestere ôt felhívta. Védelmére azt hozta fel, hogy az 1939. május 17-én kézbesített felhívás után néhány napra egy kérvényt adott be a polgármesteri hivatalhoz, melyben kifejtette, hogy ô római katolikus vallásúnak született, és így nem tartozik bejelentést tenni. Ezzel a védekezéssel szemben a polgármesteri hivatal a 36258/1939. ki. szám alatt a királyi ügyészséget arról értesítette, hogy mint zsidónak tekintendő személy e körülmény bejelentését elmulasztotta. A vád tárgyává tett cselekmény elkövetését itt is bizonyíthatónak állapította meg az ügyészség 1940. március 26-án. A per mindkét vád elejtésével, megszüntetéssel zárult. A megszüntető végzés így szólt: „E. Lajos elleni bünügyi iratokat a biróság a miskolci ügyészséghez átteszi, mert a vád tárgya olyan vétség, amely az 1897. XXXIV. tc. 17. sqakasza szerint törvényszéki hatáskörbe tartozik. A kitürött tárgyalás nem lesz. megtartva. Miskolc, február 23. Dr. Barsy sk. kir. járásbirô". ${ }^{44}$ Hogy mi lehetett ezeknek a döntéseknek az oka? Erre az ügyészségi iratok sajnos itt nem adnak választ.

Ezekben az ügyekben tehát a lényeg az volt, hogy a terhelt bizonyítsa, hogy ő nem minősül zsidónak és így nem vonatkozik rá a jogszabály által előírt bejelentési kötelezettség. Sz. Mártonnéa nyomozási jegyzőkönyvben szereplő vallomásában a következőket mondta: „A vádat megértettem. Bünösnek nem érzem magam. Én öskeresz̨ény vagyok, szüleim és nagyszülleim apai és anyai ágon keresztények." 35 Hogy hogyan merült fel az ő bejelentési kötelezettsége, vagyis az, hogy ő zsidónak minősül, erre

\footnotetext{
32 MNL BAZML VII. 51/b. 416. IV. 1023/1940.

${ }^{33}$ MNL BAZML VII. 51/b. 416. IV. 1023/1940.

${ }^{34}$ MNL BAZML VII. 51/b. 416. IV. 1023/1940.

35 MNL BAZML VII. 51/b. 417. IV. 2013/1940.
} 
ugyancsak a rendőrkapitány által készített jegyzőkönyv ad választ: „(...) ma már nem lehet megállapitani, bogy a beosztott tisztviselök és munkaerök kö̈zül ki volt a\%, aki öt zsidónak nézte, vagy gondolta. Valószínünek

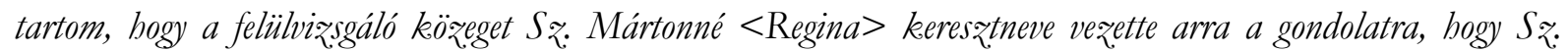

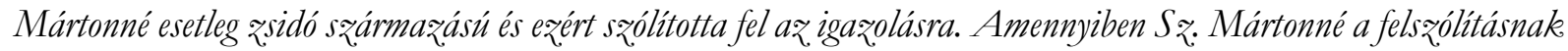
engedelmeskedett volna, és igazolta volna keresztény mivoltát, úgy a feljelentés minden bizonnyal elmaradt volna."36 A dokumentumok között megtalálhatóak bizonyítékként a keresztlevelek, amelyek alapján bűncselekmény hiányában a nyomozás megszüntetésére került sor 1940. június 20 -án. ${ }^{37}$ Hasonlóan alakult az L. Vendel elleni eljárás is, amely a polgármester feljelentése alapján indult. Miután a gyanúsított a keresztlevéllel bizonyította, hogy ő római katolikus vallású és így nem tekinthető zsidónak, a nyomozás megszüntetésére került sor 1940. május 13-án. ${ }^{38}$ Az 57 éves S. Árpád hadirokkant-igazolással bizonyította a bejelentési kötelezettség, és ezzel egyúttal a törvény alóli mentességét is. ${ }^{39}$ A 43 éves, izraelita vallású, fakereskedő foglalkozású S. Jenô ellen indított zsidótörvénybe ütköző vétség miatti eljárást a miskolci törvényszék a bizonyítékok elégtelensége miatt szüntette meg. ${ }^{40}$ A 35 éves, diósgyőri, gazdálkodóként dolgozó $V$. Györgyöt a bejelentési kötelezettség elmulasztása miatt 50 pengő pénzbüntetésre ítélte a törvényszék, amelynek végrehajtását 3 év próbaidőre felfüggesztette. A vádlott elismerte, hogy bejelentési kötelezettségét elmulasztotta, de azzal védekezett, hogy az iparát a felhíváskor megszüntette, mivel a szükséges papírokat megszerezni nem tudta. ${ }^{41}$

A legnagyobb számban, 11 esetben a strómanság, a zsidótörvény kijátszása, tehát a zsidótörvénybe ütköző vétség, illetve kihágás miatt indított eljárást a miskolci ügyészség. A strómansággal összefüggő büntetőeljárás lefolytatására a királyi törvényszék rendelkezett elsőfokon illetékességgel, míg iparral összefüggő kihágás esetén az elsőfokú iparhatóság járhatott el. A bírósági eljárás a második zsidótörvényben foglalt rendelkezések alapján indulhatott meg vétség miatt, de amennyiben zsidónak nem tekintendő személyek követték el a színleges iparűzést, akkor az nem minősült bűncselekménynek. Utóbbi esetben került sor a büntetőeljárás mellőzésével iparügyi kihágás címen közigazgatási eljárásra, és ennek során az iparhatóságnak joga volt az iparjogot is megvonni. ${ }^{42}$ Itt tehát egy hatásköri összeütközésrôl volt szó (a zsidónak minősülés alapján), mert nem volt mindegy, hogy melyik hatóság járt el az ügyben. A büntetőbíróság egy évig terjedő fogházbüntetést és 20.000 pengőig terjedő pénzbírságot is kiszabhatott, míg az elsőfokú iparhatóság az iparengedély megvonására volt jogosult, amelyet a büntetőbíróság ítélete alapján is megtehetett. ${ }^{43}$ A strómanság vétségének elkövetéséhez legalább két személy közremúködésére volt szükség. A vádlottak egyik csoportját általában olyan iparűzési jogától megfosztott, zsidónak minősülő személyek alkották, akik hatósági engedélytől függő jogosítványt, iparigazolványt szereztek olyan személyektől, akik erre jogosultsággal rendelkeztek, vagy kereskedelmi társaságok zsidónak minősülő tulajdonosai, részvényesei, irányítói voltak, akik a törvény korlátozó

\footnotetext{
${ }^{36}$ MNL BAZML VII. 51/b. 417. IV. 2013/1940.

${ }^{37}$ MNL BAZML VII. 51/b. 417. IV. 2013/1940.

38 MNL BAZML VII. 51/b. 417. IV. 1984/1940.

${ }^{39}$ MNL BAZML VII. 51/b. 417. IV. 1917/1940.

40 MNL BAZML VII. 51/b. 417. IV. 2228/1940.

${ }^{41}$ MNL BAZML VII. 51/b. 418. IV. 6527/1941.

42 BODA - VINCENTI, A Jogi Hírlap döntvénytára 44.

${ }^{43}$ LEHOTAY, Szabadságjog-megvonó intézkedések a Horthy-korszakban 282.
} 
rendelkezései alapján nem láthatták volna el ezeket a funkciókat. A strómanság megvalósulásában legalább egy zsidónak nem minősülő személy vett részt, aki az előbb felsorolt jogosítványok vagy funkciók valamelyikével rendelkezett. Ezt a személyt „szalmaembernek”” is nevezték. ${ }^{44} \mathrm{~A}$ bűncselekményt megvalósító magatartások körébe tartozott a zsidónak minôsülő személy által hatósági engedélytől függő jogosítvány megszerzése a törvény rendelkezéseinek kijátszásával. A zsidónak minősülő személy a nem zsidó vádlott nevére kiállított iparigazolvánnyal folytatta az adott kereskedést.

F. Miksa és társai ellen 1943-ban zajlott az eljárás, amely tipikus példája a strómanságnak. „O. úgynevezett stróman volt a zsidó kezében." ${ }^{45}$ 1943-ban a Dobó István 14. honvéd gyalogezred III. zászlóalj sürgősként megjelölt iratának címe: O. Jenő hentes iparának bitorlása zsidó által (zsidótörvény kijátszása). A dokumentum szerint $O$. Jenő önként feljelentette magát nemzetvédelmi tisztjénél, és előadta, hogy iparát 1938 és 1942 között F. Miksa zsidó hentes és mészáros használta. F. Miksa mindent tagadott. Az 1943 szeptemberében kelt feljelentésben a 62 éves F. Miksa gyanúsítottként szerepel, míg a 66 éves $O$. Jenô és felesége tanúként vettek részt az eljárásban. Ez azért érdekes, mert a törvény szerint a keresztény és a zsidó fél is büntetendő volt a strómanság elkövetése esetén, itt azonban $O$. Jenö tanúként szerepelt. A tényállás szerint F. Mikesa azzal védekezett, hogy azért alkalmazta $O$. Jenôt üzletvezetőként, mert az ô iparát bevonták. O. Jenố tagadta, hogy megbízást adott F. Miksának, aki 1935-ben kérte el tőle az iparengedélyét, ami 1939-ig nála volt. Ez egy újabb érdekessége ennek a jogesetnek, hiszen 1935-ben még nem volt hatályban zsidótörvény, amely $F$. Miksa iparát korlátozta volna. Mivel F. Miksa nem fizette be a húsfogyasztási adót, ezért $O$. Jenôre a pénzügyi igazgatóság pénzbüntetést szabott ki. Végül megállapítást nyert az 1939. évi IV. tc. 26. szakaszába ütköző vétség azzal az indokolással, hogy a gyanúsítottól az ipart bevonták, és ő azt keresztény ember neve alatt tovább folytatta. Az ügyben 1943-ban megszüntető határozat keletkezett, mely szerint mivel a búncselekmény elévült, az elkövetéstôl számított három év eltelt, és az elévülés félbeszakítását eredményező intézkedés nem történt, ezért a BTK 105. \3. bekezdése szerint az elévülés bűnvádi eljárás lefolytatását kizáró oknak minősült, ezért a nyomozás megszüntetésére került sor 1943. november 14-én. ${ }^{46}$

Az 58 éves N. T. Miklós ócskavas-kereskedő és társa ellen 1943-ban zsidóbújtatás címén zajlott eljárás, az ügy lényegét tekintve azonban strómanság volt. A nyomozás során megállapítást nyert, hogy N. T. Miklós ócskavas-kereskedő B. Sándor zsibárus nélkül nem adott el semmit, a vételt és az eladást is közösen végezték. Csak nyomozati és tanúvallomási jegyzőkönyvek maradtak meg, sajnos az ügy befejezése nem derült ki az iratokból. ${ }^{47}$

V. Kálmán ellen 1942-ben az ügyésznek címzett, géppel írt, névtelen („egy figyelổ aláirással) feljelentés alapján indult eljárás, amelyet azonban az ügyész megszüntetett, mivel a feljelentés „semmilyen alappal nem bir". ${ }^{48}$ A feljelentés így szólt: „Kijátszották a zsidó törvényt. Hát kérem ežt lehetöleg kivizsgálni. A nyomozás úgy lehetséges a legjobban, ha egyszerre történik Diósgyórben és Miskolcon. V a dologról talán a legkevesebbet tud, tudomásom szerint a felesége a fömakher. Tehát a férfi volna elöször kihallgatandó, és az.

\footnotetext{
${ }^{44}$ Gazdasági Jog 209.

${ }^{45}$ MNL BAZML VII. 51/b. 427. IV. 6336/1943

${ }^{46}$ MNL BAZML VII. 51/b. 427. IV. 6336/1943.

${ }^{47}$ MNL BAZML VII. 51/b. 427. IV. 6870/1943.

${ }^{48}$ MNL BAZML VII. 51/b. 418. IV. 7979/1941.
} 
emlitett kocsmáros (...) 1941. december 12." ${ }^{49}$ Ezt a feljelentést tehát az ügyész nem tekintette elegendőnek ahhoz, hogy az eljárást lefolytassa. A zsidóbújtatás címen indított eljárások is lényegüket tekintve tehát a strómanság tényállásának feleltek meg.

Kézzel írt levelében F. Béla tett feljelentést „stróman ǚlet” miatt: „Tiştelettel a tudomásukra adom, hogy Miskolcon a H. utca 51. szám alatti ü̊letnek a tulajdonosaként K. Ferencné (...) szerepel és az. iparengedély a nevére van kiállitva és árul: tejet, vajat, túrót, tojást, szóval élelmiszereket. K. Ferencné bérbe adta az iparát egy zsidónak, név szerint R.-nek és feleségének. Minthogy R.-nek elöbb ugyanabba a belyiségbe korcsmaipara volt, de mint zsidónak be kellett [zárni a] korcsmaipart, merthogy a zsidótörvényt kijátssza, $K$. Ferencné néven gyakorolja a tej, tojás és baromfi ipart. K. Ferencnét az ü̈letben még soha senki nem látta, csake R.-t, aki szombaton mindig qárva tartja ą üzletet. Amiböl világosan kitünik, bogy stróman ü̃let. R. és felesége, mint korcsmáros elég szegény embert kiqusebelt, ezért kérem, bogy K. Ferencnét, mint R-éket miután összejátszottak a zsidótörvény kijätszása miatt a legszigorúbban megbüntetni és az. ipar gyakorlásától megfosztani és a rádióját elkobozni, mivel folyton az angol bireket hallgatják. Aztán mindent drágábban árul a hatóságilag megállapitott áraknál. Tisz̨telettel: F. Béla, hadirokkant." ${ }^{\text {00 }}$ A dokumentumok között szerepelnek a tanúvallomási jegyzőkönyvek, a vagyoni és erkölcsi bizonyítványok, a rendőrségi jelentések, azonban arról nincs irat, hogyan végződött az eljárás.

1944-ben zsidóvagyon rejtegetés miatt Cs. Zoltán ellen indított eljárásról annyi információ maradt fenn, hogy a nyomozás befejezésével egyidejûleg az ügyész a mezőcsáti járás főszolgabírájához utalta az esetet, amely az 1600/1944. számú ME rendeletbe ütköző kihágást valósított meg, és ebben a fentebb említett tisztviselő rendelkezett hatáskörrel. Ez az ügy 1944 júniusában zajlott, tehát már a német megszállást követően. Az ügyészség azonban a hatáskör hiánya miatt a hatáskörrel és illetékességgel rendelkező közigazgatási szervnek továbbította az esetet. $^{51} \mathrm{Az}$ ügy befejezéséről a kutatás jelenlegi állása szerint nem áll rendelkezésünkre adat.

A másik ügytípus a fajgyalázás miatt indított eljárások köre. A levéltári dokumentumok szerint öt ilyen eljárást indított a miskolci ügyészség, mindegyiket 1943-ban.

A tanulmány bevezetőjében említett, iskolai vonalas lapra kézzel írt feljelentés alapján indított nyomozást fajgyalázás vétsége miatt $J$. Márton görög-katolikus, előzőleg zsidó vallású péksegéd ellen az ügyészség. Az iratok között megtalálható J. Márton erkölcsi és a vagyoni bizonyítványa, a részletes személyleírás, továbbá egy külön ábra a bűnözői arcformákról. 1943 januárjában a detektívi jelentés arról számolt be, hogy J. Zsuzsanna egyedül élt az említett lakásban, és „vadházas társa” J. Márton 1942 augusztusától katonai szolgálaton vett részt az orosz harctéren. J. Zsuzsanna elmondása szerint nem tudta J. Mártonról, hogy szülei zsidók. 1943 tavaszán - ahogy arról egy újabb kézzel írt jelentés tanúskodik - J. Zsuæsanna „(...) magatartását megfigyelés útján is es₹közöltéé",52, azonban bűncselekmény elkövetésére utaló jelet nem találtak. Négy „tulajdonsággaP’ kellett rendelkezni ahhoz egy személynek, hogy a fajgyalázás sértettjévé váljon. Ezek a feltételek a következők voltak: magyar állampolgárság, nemzsidó, tisztességes, nő. ${ }^{53}$ A tényállás szerint a hölgy elköltözött, és mosónőként dolgozott. 1943 nyarán kelt, kézzel írt, a detektívcsoportnak címzett

\footnotetext{
${ }^{49}$ MNL BAZML VII. 51/b. 418. IV. 7979/1941.

50 MNL BAZML VII. 51/b. 423. IV. 2047/1943.

51 MNL BAZML VII. 51/b. 442. IV. 3547/1944.

52 MNL BAZML VII. 51/b. 427. IV. 6893/1943.

${ }^{53}$ CsíkY, A fajvédelmi törvény és végrehajtási rendeletei 99.
} 
irat a következőket tartalmazta: „J. Zsuұsannát kérdeqze ki, hogy a fajvédelmi törvény életbe lépése óta közö̈sült-e J. Mártonnal? Állapitsa meg, hogy J. Zsuzsanna tisztességesnek. tekinthetö-e? Kibágási prius lapja csatolandó!" ’54 Az ügyészi határozat szerint sor került J. Zsuzsanna bejárónő tanú kihallgatására, aki 1940 és 1942 között közös háztartásban élt a gyanúsítottal, akinek a szülei zsidók voltak. Elmondta továbbá azt is, hogy nem tekinti magát tisztességes nőnek, mert tiltott kéjelgés miatt többször büntetve volt, amelyet a kihágási büntetési törzslappal bizonyított. Mindezek alapján került sor a nyomozás megszüntetésére 1943. december 31-én a Bűnvádi Perrendtartás 101. szakaszára hivatkozással azzal az indokolással, hogy a feljelentés tárgyát képező vétség tényálladéka nem valósult meg. Ez a per több, a fajgyalázási perekkel összefüggésben felmerülő kérdésre adhat választ. A fajgyalázási perek, ahogyan arra Nagy Sándor is utalt a tanulmányában - a gyanúsított személyek legszemélyesebb viszonyait érintették. Felmerül a kérdés, hogyan indultak ezek a perek. Az itt ismertetett eljárás lehet az utóbbi kérdésre az egyik válasz: névtelen feljelentéssel, aláirás és dátum nélkül, feltehetôleg 1942 őszén/telén. Később a nyomozás során is rögzítették, hogy a gyanúsított 1942 nyarától katonai szolgálaton volt. Az ő kihallgatására tehát egyáltalán nem is került sor. A tanúként meghallgatott J. Zsuæsannát megfigyelték, kihágási törzslapját ellenőrizték, ő időközben elköltözött a Vörösmarty utcából, és végül - miután tisztességtelennek vallotta magát, és ezt a kihágási törzslapja is megerősítette - a nyomozást megszüntették.

Egy másik eljárásban W. Izৃidor 54 éves, izraelita vallású, budapesti születésú lakost ugyancsak 1943-ban az ügyészség fajgyalázás vétségével vádolta meg. A vádirat szerint 1943. július 26. és július 30. között zsidónak tekintendő személyként $D$. Eržsébet „magyar honos, tisztességes nem zsidó növel házasságon kivül több alkalommal nemileg közösüll’" ${ }^{55}$ A vádlott tagadta ezt, és azzal védekezett, hogy jó ismerősként laktak együtt a nyaralás ideje alatt egy szobában négy napig. Ezt azonban az ügyész nem fogadta el a fennálló körülményekre tekintettel, miszerint „egy szobában egymás mellett lévő ágyban aludtake négy napon keresztül, továbbá az ágyakban a közösülés megtörténtére mutató nyomok vannak." 56 A vádlottat előzetes letartóztatásba helyezték, amely ellen a védője felfolyamodással élt, ezt a törvényszék elfogadta, és mivel „a szökéstöl tartani nem kell "57, így az előzetes letartóztatást megszüntette. 1944. május 16-án az ügyész a törvényszéknek írt levelében indítványozta az „ismeretlen helyen” tartózkodó vádlott ellen a személyi körözés kibocsátását, annak eredménytelensége esetén pedig az eljárás megszüntetését. Az ügyben a miskolci törvényszék nem nyilvános ülésen végzést hozott 1945. június 23-án(!), amelyben az eljárást megszüntette, miután az ügyészség a vádat tárgyaláson kívül ejtette.

A harmadik eljárás fajgyalázás miatt $W$. Tibor ellen első fokon a miskolci törvényszéken, majd másodfokon a kassai ítélőtáblán zajlott. Ez az egyetlen olyan eljárás a vizsgált jogesetek közül, amelyben marasztaló ítélet született. Az elsőfokú bíróság 500 pengő pénzbüntetésre és egy évi hivatalvesztésre, valamint a politikai jogok gyakorlásának felfüggesztésére ítélte a vádlottat. Ezt követően az itélőtábla nem nyilvános főtárgyaláson megváltoztatta az elsőfokú bíróság ítéletét és felmentette a vádlottat. A tényállás lényege az volt, hogy a sértett és a vádlott egymást gyermekkoruk óta ismerték, jó barátságban voltak egymással és egy fürdőhelyen egymás melletti nyugágyon

\footnotetext{
${ }^{54}$ MNL BAZML VII. 51/b. 427. IV. 6893/1943.

${ }_{55}$ MNL BAZML VII. 51/b. 426. IV. 4864/1943.

${ }^{56}$ MNL BAZML VII. 51/b. 426. IV. 4864/1943.

${ }^{57}$ MNL BAZML VII. 51/b. 426. IV. 4864/1943
} 
napoztak, miközben a vádlott egy ízben megcsókolta a sértett kezét. Az ítélőtábla a gyanú keltésére alkalmas tényeket vizsgálta, és arra jutott, hogy a sértett és a vádlott nem lépték át „a tisztességes társas érintkezés kereteit." ${ }^{\prime 8}$ Érdekessége a pernek, hogy a felmentő itéletében az itélótábla iránymutatást is adott az elsőfokon eljáró bíróság számára, amely tévesen jelölte meg a bűncselekményre vonatkozó törvénycikk szakasz számát. A törvény ugyanis szabályozta a fajgyalázás vétségét és bűntettét is.

Bírósági szakba jutott E. Tibor ügye is, amelyben csalárdsággal elkövetett fajgyalázás (másik megfogalmazás szerint: fajvédelem elleni bủntett) miatt a miskolci törvényszék a Bủnvádi Perrendtartás 326. szakaszának 2. pontja alapján - mely szerint, ha a vád tárgyává tett cselekmény, vagy az, hogy a vádlott követte el, nincs bizonyítva - felmentő itéletet hozott 1943. július 1-jén. ${ }^{59}$

Az ötödik fajgyalázási eset iratai alapján egy bonyolult családi dráma eseményei tárulnak elénk, amelyben a csalás miatt szigorított dologházban lévő T. Andor a saját feleségét jelentette fel. Továbbá fajgyalázással vádolta meg a zsidó F. Sámuelt, majd K. Józsefet, akikkel a felesége szerelmi viszonyt folytatott. Feleségét (akitől különvált) továbbá sikkasztással is megvádolta, mert a ruháit és egyéb személyes tárgyait nem adta neki vissza, miután köztük az életközösség megszakadt. A levéltári dokumentumok között számos magánlevél, tanúvallomás és jegyzőkönyv található. A kihallgatás során a gyanúsítottak tagadták az ellenük felhozott vádakat. K. József elismerte, hogy T. Andor feleségével közös háztartásban élt, azonban azt tagadta, hogy ő zsidó lenne (bár ezt dokumentumokkal bizonyítani nem tudta). Mindezek alapján a nyomozást megszüntették, mert az ügyészség szerint a feljelentő vádjait alátámasztó és releváns bizonyítékokat nem sikerült feltárni. ${ }^{60}$

Megállapítható mindezek alapján a fajgyalázás miatt indított eljárásokról, hogy a rendelkezésre álló ügyészségi dokumentumok szerint viszonylag kevés ilyen jellegü eljárás indult, volt olyan, amely el sem jutott a vádemelésig, ahol pedig perre került sor, az megszüntetéssel vagy felmentéssel végződött. Ugyanakkor - mint ahogy arról fentebb szó volt - még 1945-ben is foglalkozott a bíróság fajgyalázási üggyel. A fajgyalázási eljárások jelentik azoknak az eseteknek a körét a zsidótörvényekkel kapcsolatos ügyeken belül, amelyek közül a legtöbb bírósági szakba jutott. Az ügyészségnek ezekben az esetekben meghatározó szerepe volt, mert az érintett személyek magánéletében (az együttélés formája és ideje, a kapcsolat jellege, a társas érintkezési formák mélysége) kellett nyomozni ahhoz, hogy megalapozott legyen a vád.

Összegzésként rögzíthető, hogyan zárultak illetve hogyan értek véget a tanulmányban vizsgált ügyek. A feltárt 23 eljárás jelentős része már a nyomozási szakaszban befejeződött, tehát el sem jutott az ügy a bíróság elé, vagy ha igen, akkor felmentô ítélet született. 4 esetben nem derült ki az ügyészségi iratokból, hogyan zárult az eljárás. A 23 esetből mindössze 2 ügy jutott el bírósági szakaszba. Elsőfokon mindkét esetben marasztaló itéletet hozott a bíróság, $V$. Györgyöt zsidótörvény kijátszása miatt pénzbüntetésre ítélték, de az ítélet végrehajtását három évre felfüggesztették. ${ }^{11}$ A másik eljárásban az elsőfokú bíróság $W$. Tibort fajgyalázás vétségében bűnösnek mondta ki, azonban az ítélőtábla felmentô itéletet hozott. ${ }^{62}$ A vizsgált ügyek közül 9 esetben a Bűnvádi Perrendtartás 101. szakaszának 1. vagy 3. pontjára hivatkozással szüntette meg

\footnotetext{
58 MNL BAZML VII. 51/b. 426. IV. 4865/1943.

${ }^{59}$ MNL BAZML VII. 51/b. 423. IV. 57/1943.

${ }^{60}$ MNL BAZML VII. 51/b. 425. IV. 3494/1943.

${ }^{61}$ MNL BAZML VII. 51/b. 418. IV. 6527/1941.

${ }^{62}$ MNL BAZML VII. 51/b. 426. IV. 4865/1943.
} 
az ügyészség az eljárást még a nyomozási szakaszban. A jogszabály szerint a nyomozást meg kellett szüntetni, ha nem forgott fenn bűncselekmény, vagy ha bizonyítékok hiánya vagy azok megszerzésének rendkívüli nehézsége miatt eredményt nem lehetett várni az eljárás további folytatásától. ${ }^{63}$ Erre a jogszabályhelyre hivatkozással ért véget a zsidótörvény kijátszása miatt indult eljárás is, amikor kiderült, hogy a vádlott zsidónak nem tekintendő személy volt, ezért bejelentési kötelezettséggel sem tartozott. ${ }^{64}$ Egy esetben a Büntetőtörvénykönyv 105. szakaszának 3. pontjába foglalt elévülés miatt ért véget az eljárás. ${ }^{65}$ Ugyancsak egy esetben került sor a Bủnvádi Perrendtartás 232. szakasza alapján a bizonyítékok elégtelensége miatt az eljárás megszüntetésére. ${ }^{66}$ Mindezek alátámasztják Nánási kutatásának eredményeit, mely szerint a fajgyalázás miatt indult eljárások száma csekély volt és a nyomozások nagy részét megszüntették. A kevés vádemelés jelentős része is eredménytelenül ért véget, mert az ,igen labilis bizonyitékookat a biróság nem honorálja marasztalással'. ${ }^{67}$ Szintén Nánási ismertette a bíróságok és ügyészségek vezetőinek 1944 nyarán készült jelentéseit, amelyeket az igazságügyminiszter kérésére készítettek el. Ezek szerint a társadalomban „a jogtisðtelet hanyatlása” terjedt el, a túlszabályozottság súlyosan érintette „egyesek lényeges érdekeit’, továbbá a zsidó lakossággal történtek hatására létrejött az a képzet, hogy ,az̧t holnap másokkal szemben is alkalmazni lehet, ami nem csekély oka a törvény biztosságába vetett hit meglazulásának". ${ }^{68}$ A miskolci ügyészség elé került és fennmaradt viszonylag kevés ügyből levonható az a következtetés, hogy az ügyészség a törvény betújéhez ragaszkodva járt el, mindenre kiterjedő nyomozást folytatott le, és inkább ejtette a vádat, ha a bizonyítékokat elégtelennek találta, tehát nagyon óvatosan kezelte a zsidótörvényekkel kapcsolatos ügyeket.

\section{Záró gondolatok}

A tanulmány záró gondolataként felmerül az a kérdés is, hogy mire utal(hat) a rendelkezésre álló levéltári dokumentumok csekély száma. Az ügyészségi iratokból leszűrhető adatokat, számokat óvatosan kell kezelni, mert ez egyrészt a források hézagosságára mutathat rá a borsodi zsidóság számarányát figyelembe véve. Elképzelhető az is, hogy ezeket az iratokat kiválogatták és egy részüket megsemmisítették, de erre választ csak akkor tudnánk adni, ha több megye adatait tudnánk összehasonlítani. Ugyanakkor az is lehetséges, ahogy arra Nagy is utalt, hogy vidéken valóban viszonylag kevés zsidótörvénnyel összefüggő eljárás indult. Ez nemcsak a fajgyalázási perekre, hanem általában a zsidótörvényekre is igaz, és e kutatás mostani állása is ezt a megállapítást erősíti. Elmondható az is, hogy az országos tendenciának megfelelően alakult Borsod megyében a zsidótörvényekkel összefüggésben zajló eljárások befejezése. A föügyészségi jelentések szerint, amelyeket az Igazságügyi Minisztériumhoz kellett felerjeszteni, a vidéki ügyészségeken kevés ügy fordult elő, és ezek száma is csökkent. ${ }^{69}$ Országos szinten a törvényszékek marasztaló ítéletet a

\footnotetext{
63 1896. évi XXXIII. tc. a bűnvádi perrendtartásról

${ }^{64}$ MNL BAZML VII. 51/b. 417. IV. 2232/1940.

${ }^{65}$ MNL BAZML VII. 51/b. A 427. IV. 6336/1943.

${ }^{66}$ MNL BAZML VII. 51/b. 417. IV. 2228/1940.

${ }^{67}$ NÁNÁsI, A magyar királyi ügyészség története 410.

${ }^{68}$ NÁNÁsI, A magyar királyi ügyészség története 439.

${ }^{69} \mathrm{NAGY}$, A fajvédelem útvesztőjében 488.
} 
fajgyalázási ügyek 15 százalékában hoztak. ${ }^{70}$ Borsod megyében az 5 fajgyalázási perből egyetlen egy esetben hozott az elsőfokú bíróság marasztaló ítéletet, másodfokon azonban ebből is felmentő ítélet született. Elképzelhető, hogy más név alatt, más bűncselekményi kategóriába sorolva is folytak zsidótörvény alapján eljárások, így például a gazdasági bűncselekmények körében. Úgy gondolom, hogy teljes képet a jogszolgáltató szervek (köztük az ügyészség) 1938 és 1944 közötti múködéséről akkor kaphatunk, ha a tanulmány elején feltett kérdésre - azaz hogy mennyiben gyorsították vagy lassították a jogszolgáltató szervek a diszkriminációt - a további kutatások alapján válaszolni tudunk.

\section{Felhasznált források és irodalom}

Magyar Nemzeti Levéltár Borsod-Abaúj-Zemplén Megyei Levéltára (MNL BAZML) VII. 51/b. A Miskolci (Királyi) Ügyészség. Államügyészség iratai

KUNCZ Ödön (szerk.): Gazdasági Jog (1940 - 1944). I. évf. 1. sz. Budapest 1940 január

BODA Gyula - VINCENTI Gusztáv (szerk.): A Jogi Hírlap Döntvénytára. Magánjog. V. köt. Budapest 1942

BERÁNNÉ Nemes Éva - Román János: Miskolc története. Borsodi Történelmi Évkönyv 5/1. IV. kötet. Miskolc 1981 CsíkY János: A fajvédelmi törvény és végrehajtási rendeletei. Budapest 1941

ECKHARDT Ferenc: Magyar alkotmány-és jogtörténet. Budapest 2000

FINKEY Ferenc: A kir. ügyészség teendôi az új büntetőnovellával kapcsolatban. Budapest 1928

SzEGEDI Gábor: Good Health is the Best Dowry: Marriage, Counseling, Premarital Examinations, Sex Education in Hungary 1920 - 1952. Budapest 2014

HORÁNYI Miklós: Fejezetek az ügyészség 130 éves történetéből 1871 - 2001. Budapest 2002

KARSAI László: A magyarországi zsidótörvények és rendeletek 1920 - 1944. In: MOLNÁR Judit (szerk.): A holokauszt Magyarországon európai perspektívában. Budapest 2005, 140-163.

KATZBURG, Nathaniel: Zsidópolitika Magyarországon 1919 - 1943. Budapest 2002

LEHOTAY Veronika: Szabadságjog-megvonó intézkedések a Horthy-korszakban, különös tekintettel a zsidótörvényekre. Miskolc 2013 http://www.uni-miskolc.hu/ wwwdeak/lehotayv_ertmh.pdf

(letöltve: 2018. 06. 29.)

LugOSI András: „Sztalin főhercege.” Kohn báró vacsorái a Falk Miksa utcában a fajgyalázási törvény idején. Fons XVII. 2010/4. 527-576.

NAGY Sándor: A fajvédelem útvesztőjében. Bírói gyakorlat „fajgyalázási” perekben (1942 - 1944) Fons XXII. $2015 / 4$. $487-588$.

NÁNÁsI László: A magyar királyi ügyészség a II. világháború idején. http://acta.bibl.uszeged.hu/30709/1/juridpol_doct_009_249-305.pdf (letöltve: 2018. 06. 29.)

NÁNÁsI László: A magyar királyi ügyészség története. Budapest 2011

NÁNÁsI László: A magyar királyi ügyészség története. Szeged 2011. http://doktori.bibl.uszeged.hu/895/1/Nanasi_Laszlo_ertekezes.pdf. (letöltve: 2018. 06.29.)

NÁNÁsI László: Különleges nyomozószerv a második világháború idején. Az Államvédelmi Központ Ügyésze. http://epa.oszk.hu/01200/01268/00018/pdf/EPA01268_betekinto_2011_2_nanasi_0.pdf (letöltve: 2018. 06. 06.)

PÜSKI Levente: A Horthy-rendszer. 1919 - 1945. Budapest 2006

SCHWEITZER Gábor: A zsidótörvények a Közigazgatási Bíróság ítélkezési gyakorlatában. In: MoLNÁr Judit (szerk.): A holokauszt Magyarországon európai perspektívában. Budapest 2005, 164-175.

SZENTMIKLÓsI István: A házassági per kézikönyve. Budapest 1942

SzITA Szabolcs: Halálerőd. Budapest 1989

\footnotetext{
${ }^{70}$ NAGY, A fajvédelem útvesztőjében 488.
} 